\title{
Reform and Upgrade of College English Teaching Methodology under the Perspective of Culture and the Humanities
}

\author{
Runhua Yang ${ }^{1}$ \\ ${ }^{1}$ Chengde Radio and TV University, \\ Chengde,Hebei,067000 China
}

\author{
Xiaodong Sun ${ }^{1}$ \\ ${ }^{1}$ Chengde Radio and TV University, \\ Chengde,Hebei,067000 China
}

\begin{abstract}
In this paper, we conduct research on reform and upgrade of college English teaching methodology under the perspective of culture and the humanities. As a necessary social language, English has become increasingly occupies the important position in the work and study, college English teaching in China from the initial start gradually to start from the primary school started teaching. Students need is to be able to give full play to their own learning subject initiative, and in the process of continuously explore and learn knowledge for the own needs. Our method solves the issue.
\end{abstract}

Keywords: College English Teaching; Culture and the Humanities; Reform and Upgrade.

\section{Introduction}

College English teaching reform is to college English teaching from the traditional pattern of stuffing to shift gradually to the interactive mode, this article through the relevant theoretical analysis in the current college English teaching of college English teaching reform in education environment, the necessity of English teaching in colleges and universities the status quo and existing problems, and put forward the corresponding improvement measures, how to get the college English teaching reform of college English teaching practice is very important. Through the theoretical analysis method to the easier it is concluded that the reform of college English teaching related factors play a substantial role in it. Economic globalization makes the enterprises need a lot of English related comprehensive talent, for the college English teaching is an important opportunity of development, at the same time, also for the teaching quality of higher requirements are put forward. The traditional English teaching will not only affect the improvement of students' English practical, more will affect the ability of the students' employment. Mode of college English teaching content and the depth of the reform is to promote the improvement of students' English comprehensive ability has important value of education. As a necessary social language, English has become increasingly occupies the important position in the work and study, college English teaching in China from the initial start gradually to start from the primary school started teaching, English teaching mainly is to promote English learners' English listening ability, can skilled language communication and meet the needs of textual work, how to make learning personnel in practical English learning quickly learn related knowledge has become a bottleneck of college English teaching, how to play in the practical use of English learning has become a crucial point in teaching English [1-2].

Education one-sided emphasis on the language itself and ignore the cultural connotation, the most prominent performance is all levels of language proficiency test, a series of test make teachers and students are struggling to cope with the teacher's teaching is restricted, student learning is misleading, as a result, the teachers are busy speak words speak grammar speaking 
reading writing, students are mechanical memorizing words grammar composition practice reading practice, the university classroom completely lost its atmosphere, university education has lost its meaning and function. In current college teaching in China except a few liberal arts schools generally there is a problem that is the lack of humanistic education. In addition to political theory lessons, the liberal arts foundation course seems to be only in English. College English education should make full use of the advantages of the existing, play its proper role. Statistics show that China's college students, the level of Chinese and Chinese culture knowledge are weak in general. As we could imagine what it's like to be their language and cultural knowledge and the lack of humanistic education at the university of strictly speaking, cannot call the university at best higher technical school. Of course, in the process of introduction and culture learning a foreign language and there has been a sensitive problem that is the ideological differences which is hard to deal with [3].

Therefore, to upgrade and optimize the current teaching pattern and methodology, we research on the reform and upgrade of college English teaching methodology under the perspective of culture and the humanities in this paper. College English teaching from pure language teaching to attach importance to cultural education, it also will inevitably put forward some higher requirements to teachers' quality. Skilled master the English language itself is the most basic requirements and the Chinese style English is bad, because it will mislead students directly and should not appear. In the following sections we will introduce our approach in detail.

\section{Our Proposed Methodology and Perspective}

The Principle of Culture and the Humanities.

Humanities education has always been one of the important content of education, especially the traditional culture of our country, extensive and profound the ancient burning today with the bright light of humanities, this is a valuable education resources and also is very good tool of moral education. A profound traditional culture of the Chinese nation and its education idea and the humanistic spirit itself is the content of moral education. Humanistic education is to the human outstanding culture achievements. The humanities through knowledge, environmental influence, and make into individual personality, accomplishment, become a relatively stable internal quality. Human mass line is the humanities education reflects the result of the education object. Humanistic quality including language training and teaching, literary and artistic accomplishment, ethical and moral cultivation, civilized manners, history and philosophy, political theory, social culture, etc. [4]. The current all countries in the world are considering how to strengthen humanities education, how to strengthen the education of life, how to make the development of social economy and the improvement of moral harmony which make the humanities education and science education penetrate each other. We believe that the sense of responsibility is a person is aware of and determined to fulfill personal obligations denoted as the reflection of social roles, goals and personal development is the manifestation of national development goals consistent which is also a driving force for the development of the individual.

Education as a mass behavior, there must be a fit for a certain period, a group of education theory for guidance. Moral education in colleges and universities, the education activities, with a broad range of meaning in our country at present stage and before and after the practice of moral education, is inseparable from the humanistic education theory contribution. In fact, any discipline, the field has the humanities education content, can have a positive or negative results of humanistic education such as natural science actually contains profound humanistic education content. Every natural science history and culture, the development of the main way of thinking, 
scientists, scientific spirit and humanistic spirit and so on is the humanities education content. Backward thinking and the negative effect on the people may be more. Besides the disciplinary education, the humanities education also is everywhere, any environment system, the practice may affect human development and there are the content and requirements of humanistic education.

Humanities research object is the humanities world, also is the people's spiritual world and cultural world. People's spiritual world and cultural world is unified. From the content, the people's spiritual world and cultural world are meaning world and value world. Human spirituality, significance and value of the world determines the unique properties of humanities from sociology, the humanities has the characteristics of the experience and enlightenment and valuation.

\section{The Current English Teaching} Methodology. In recent years, college English teaching with the development of education and the economy has made no small achievement and English professional talent output has increased a lot. Most of the college English teaching management process, often relying on the corresponding management system. However, after making a lot of management related system which has not been effectively update, so that there is often a lag. Teaching inspection system is mainly for teachers, for example, attitude of timeliness, students in the class lectures, such as innovation on the teaching content and teaching method as well as the degree of innovation and proficiency in the use of new technologies is not serious. Part of college English teaching management process, often more attention to teacher's teaching process, but does not focus on students' learning effect. For teachers' teaching quality assessment is not scientific, can't really tell difference teaching level. Teaching quality evaluation system set up scientific or not directly affects the quality of English teaching, English teachers have lead, motivate and supervise and judgment, and other functions. Some universities need to improve English teaching quality evaluation system construction. Teachers' professional teaching ability has a great impact on the quality of teaching. At present, some universities, especially the ordinary undergraduate course colleges and universities, the education level of English teachers' team needs to improve. Many teachers in the teaching work are laden with heavy teaching tasks and it could not have enough time for teaching theory research more can't devote to the teaching and scientific research. These factors make the English teachers know little about the latest teaching theory, it is difficult to in the teaching process of the depth of the teaching research, leading to the teaching contents and teaching methods of shows certain hysteresis.

Under the situation, more modification should be adopted to change the current teaching pattern. Students need is to be able to give full play to their own learning subject initiative, and in the process of continuously explore and learn knowledge for the own needs. Therefore, the teacher in the teaching process according to the actual needs of students in English learning, develop appropriate teaching methods. In the following section, we will introduce our proposed method.

The Culture and the Humanities Combined Teaching Pattern. Language as a communication tool, as express different cultural, political, religious, can be successfully used for learners, can express themselves and communicate with others is the real purpose of learning. The reform of college to be a focus is to provide students with a truly can use pure English communication platform for teachers and students to create an English speaking environment and atmosphere. But now the fact that is not part of the teacher's voice is qualified English phonetic pronunciation requirements, students cannot feel the charm of English in a good environment. Teaching reform, the core is that students and teachers, the teaching method 
reform is Paramount. First, the teacher must set up take the student as the center of the classroom teaching idea, knowledge teaching of the non-computer majors teaching approach into question. Let students themselves to find problems, thinking, discuss in groups to find the answer, finally the teacher answers. In the following figure one, we visually describe the proposed teaching patter as the flowchart.

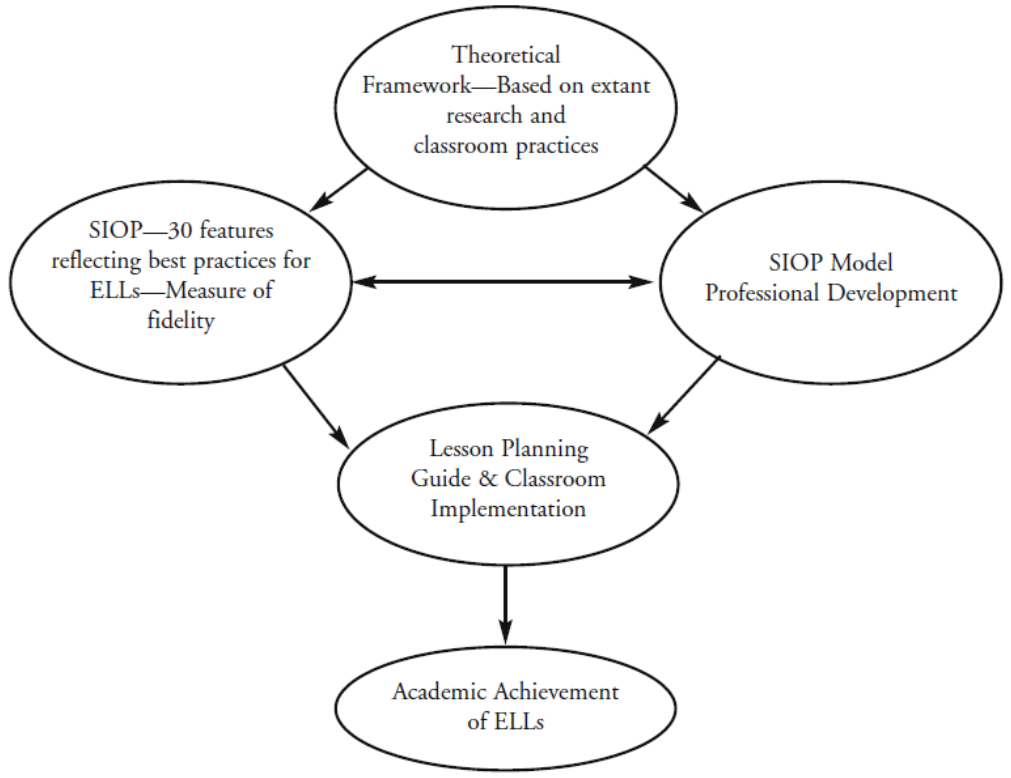

Figure 1. The Basic Strucure of the Proposed Teaching Model and Pattern

With the advancement of modern teaching equipment, teaching method in colleges and universities gradually show the diversification and modernization. However, similar to the multimedia teaching such as teaching means has not been fully used. First of all we should finalize the management system reform and innovation. Break the traditional focus on the management of teaching process and ignore the teaching results. The teaching quality of colleges and universities should set up special supervision evaluation mechanism, from the teacher prepares a lesson to the homework, and then to test quality evaluation link to system regulation. At the same time, also can be randomly draw a certain number of students on a regular basis, to the English comprehensive evaluation, in order to better grasp the teacher's teaching effect, thus appropriate rewards and punishment of teachers, to urge the teaching goal. Secondly, with the aid of competition mechanism, to truly inspire teachers' work enthusiasm, can make full use of teaching competition mechanism and in the whole teaching team set up the competition mechanism, make the teacher has a certain sense of crisis, thus more actively into practical teaching. School in English teacher's title appraisal standard evaluation process can consider to will be divided into English teachers "teaching" and "fine" two kinds big. The college English teaching as an important part of university education will meet with challenges. Thus the future college English teaching will gradually from pure language skills teaching on the basis of language, to emphasis on students thinking, cultivate the students' independent thinking shift, from a mere knowledge to broaden the students' field of vision, improve students' humanities accomplishment, from simple language comprehension and application of the shift to a high level of language and culture appreciation. And college English course may yet by now unified teaching material teaching compulsory to multi-level and diverse electives.

The Prospect and the Suggestions. While in college English teaching, there are a series of 
unsolved problems, but college English education will continue to survive. First of all, it is the humanistic quality education function is indispensable in the education of colleges and universities, and any other education cannot replace. Second, college English education is the current political, economic and cultural development of the inevitable requirement of the fast globalization trend. Communication between different ethnic groups increased contact, inevitable requirement language is same but it is only shallow levels of basic communication. If we want to get further communication, we must understand each other's culture. Last but not least, the culture combined English education pattern should be adopted to enhance the performance of the teaching activity.

\section{Conclusion}

This paper conducts survey and research on the reform and upgrade of college English teaching methodology under the perspective of culture and the humanities. The reform of college to be a focus is to provide students with a truly can use pure English communication platform for teachers and students to create an English speaking environment and atmosphere. But now the fact that is not part of the teacher's voice is qualified English phonetic pronunciation requirements. Our method could combine advancement of culture influence together with basic teaching model which will gain satisfactory result. In the future, more related survey will be conducted.

\section{References}

[1] Jian-rui, C. (2014). The exploration and practice of opening experiment teaching in computer-assisted college English. Computer Knowledge \& Technology.

[2] Anhong, L., \& Ke, X. (2014). Corpus-based college English vocabulary teaching mode and the teaching effect. Journal of Chongqing University of Arts \& Sciences.

[3] Guo-fang, H., \& Department, F. L. (2014). A study on student-centered model of college English teaching in colleges for nationalities. Journal of Changchun University.

[4] Chun-lin, L., \& Academy, G. P. (2014). A study on integration of task-based approach with process-oriented assessment in college English teaching - taking higher vocational college English teaching as an example. Journal of Guangxi Police Academy. 